\title{
The Syrian Refugees Crisis in Increasingly Fragmented International Law: Is the EU - Turkey Readmission Agreement in Accordance with International Law?
}

\author{
Buğrahan BICAN
}

\begin{abstract}
One of the world's most chaotic and devastating civil war has been sustained since March 2011 in Syria. This Syrian Crisis has transformed much more complex, unpredictable and atrocity in this region than the guess of the states. Different conflicting actors, intervening states (and also their different interest/motivations) and also unprepared international society led to dead end or cul-de-sac for this sudden crisis. At the same time, Syrian refugee crisis appeared for neighbor and European states on the agenda. None of these states had prepared for this kind of migration and number of community. 1951 Geneva Refugee Convention is the main legal document that is relating to define refugee, their rights and obligations of states. Nonetheless, some of exceptional clauses (geographical exception clause of the Turkey), some of European states domestic policies and their domestic policy pressures and Civil War which became more desperate view in the time; these conditions force to the international society and the states to create new process and legal structure for this crisis. EU - Turkey refugee deal and agreement can be eventual consequence in this process. In fact, it is continuing process. As well as, is this process legalized enough yet? In other words, how much is it legalized or which is stage in this process? All of these questions are still waiting to be answered. Some summits, official and unofficial meetings and works for drafting have already been made since the beginning period of the crisis but these attempts and initiatives are seem to be questionable for the effectiveness. Could these developments be creating fragmentation in international law?
\end{abstract}

Keywords: Syrian Crisis, Civil War, Legalized, Process, Refugee, Agreement.

\section{INTRODUCTION}

When the Syrian civil war began in March 2011, influx of refugees began with small groups. After that their numbers grew and grew much more inevitably with continuing and complex chaotic situation in the following process. Many Syrian civilians stayed in the crossfire among different positioned combatants such as; Regime forces, ISIS and Al-Nusraetc ${ }^{1}$. Many different fractions and combatant sides are fighting each other in this country. In addition, the region was shattered many autonomous or half-autonomous zones ${ }^{2}$.

Briefly, some management gaps appeared in these zones. Millions of Syrian Refugees are fleeing from these zones. Great majority of these civilians are aim to reach-relatively-safer places which are neighbor states such as; Turkey, Egypt, Lebanon and Iraq. Their follow-up and main objectives are arriving to Northern and Western Europe. Thus, their death-defying and dangerous land and sea routes appeared. These route follows: from the Syria or Iraq borders to Turkey and on the Tukey borders to Bulgaria or Greece land borders (land route) or their sea route follows from Turkey's west and south sea coasts to Greece/Italy ${ }^{3}$ or they can follow the sea route from Tunisia to Italy or from Morocco to Spain alternatively ${ }^{4}$.

\footnotetext{
${ }^{1}$ Historical process of Syrian Crisis; Syria: The Story of Conflict (11 March 2016), BBC News; http://www.bbc.com/news/world-middle-east-26116868. Date of Access: 2 April 2016; Conflict Background, I am Syria; http://www.iamsyria.org/conflict-background.html. Date of Access: 3 April 2016; "Başlanglcından Günümüze Suriye Krizi”; http://www.birgun.net/haber-detay/baslangicindan-gunumuze-suriye-krizi104693.html. Date of Access: 2 April 2016; "Suriye Krizi"; http://tr.sputniknews.com/trend/suriye_krizi/. Date of Access: 3 April 2016.

${ }^{2}$ Look at Syria live map; http://syria.liveuamap.com/. 9 April 2016.

${ }^{3} 6$ charts and a map that show where Europe's refugees are coming from - and the perilous journeys they are taking: Record numbers of people fleeing war, persecution and poverty are entering the EU (2 September 2015); http://www.independent.co.uk/news/world/europe/refugee-crisis-six-charts-that-show-where-refugees-arecoming-from-where-they-are-going-and-how-they-10482415.html. Date of Access: 2 April 2016.

${ }^{4}$ The Sea Route to Europe: The Mediterranean passage in the age of refugees (1 July 2015), the UN Refugee Agency; http://www.unhcr.org/5592bd059.html. Date of Access: 10 April 2016, p. 3, 9.

DOI: $10.9790 / 0837-2109040112 \quad$ www.iosrjournals.org $\quad 1 \mid$ Page
}


Although some European states accept some portion of these incoming civilians, many of them took some measures such as; border closure, took military measures and returning refugees ${ }^{5}$. Meanwhile, close to ten thousand refugees died in these sea routes in last two years ${ }^{6}$. In present time, Mediterranean Sea turned into one of the biggest cemetery ever in this world.

In this research paper will be examined Syrian refugee process from beginning to present. Neighbor states and European states' measures which are related to cut off the flow of the refugees and they want finish or-at least-diminish to deaths in this sea route. Some official and unofficial meetings are being made between the region states and European states. In addition, some regulations (such as Dublin regulation) will be researched whether adequate for both arrival/participating sea rescue operations states and refugees conditions. International law and world states' attempts to create better conditions whether or not for maintaining Syrian refugees' security. In addition, the answer will be searched for the question of what kind of editing or measures can be done by the international society?

It should be noted that, this work will use different evaluation for this problem. It will be examined from legalization process from the beginning of crisis to current situation of the region. Main question will be around how much is it whether legalized or not? Furthermore, how is the relationship between legalization and measures effective on situation of the region?

In this work, the first chapter will explain historical background of conflicts and Syrian refugees' migration period. This period will be accepted as "process"7 and it will be explained on this terminology. The following chapter, it will examine legalization ${ }^{8}$ term and also this will be evaluated to how much legalize process in relationships between European Union and Turkey. Especially, EU-Turkey refugee deal and its consequence; the agreement is playing important role to determine refugee density. I assume that legalization level of EU-Turkey agreement lights us to the future of this "process" and also Syrian refugee crisis.

\section{HISTORICAL BACKGROUND}

\section{A. Background of the Syrian Civil War and Conflict}

In 15 March 2011, civil revolt appeared against Assad-Baas regime. Some upheavals were begun under the influence of Arab uprising Daraa in Syria. Syrian army fired the insurgents in April. Thus, civil war began. In following period, government of Assad declared general amnesty and released some political prisoners and also government resigned. Nonetheless, conflict between insurgents and the army intensified in the following months. Meanwhile, first Syrian refugees passed the borders and came to the Turkey and other neighbor states. In addition, the Free Syrian Army (FSA) was established to fight against the Assad regime?

When the war between army and insurgents transformed into the Alawite-Sunni sectarian strife, then AlQaeda (derived branch later well-known ISIS) suicide bombing attacks started in 2012. Many civilians stayed under fire from different groups and factions. Intensified conflict and demolition caused to leave huge number of Syrian citizen ${ }^{10}$.

\section{B. Syrian Refugee Crisis Timeline}

As we noted that the migration started April 2011. In following period, Syrian citizens spread all over the region and neighbor states. Most of neighbor states facilitated refugee camps in Turkey, Jordan, Lebanon, Egypt and Iraq $^{11}$. If we look places that the share of local camps and most concentrated refugee population, we can see that the Turkey is taking the lead from these points in this region. Now, 2,749,140 Syrian refugees reside in Turkey and also this number tends to increase for the future. This can be the highest number of refugee

5 Europe's Refugee Crisis: An Agenda for Action (16 November 2015), Human Rights Watch; https://www.hrw.org/report/2015/11/16/europes-refugee-crisis/agenda-action. Date of Access: 11 April 2016. ${ }^{6}$ Syria's refugee crisis in numbers (3 February 2016), Amnesty International;

https://www.amnesty.org/en/latest/news/2016/02/syrias-refugee-crisis-in-numbers/. Date of Access: 11 April 2016.

${ }^{7}$ Higgins, R., Problems \& Process: International Law and How We Use It, Clarendon Press-Oxford, 1994, p. 2-3. ${ }^{8}$ Goldstein, L. J., Miles Kahler, Robert O. Keohane, Anne-Marie Slaughter, Introduction: Legalization and World Politics, Legalization and World Politics, The MIT Press, 2001, p. 2, 8; Brütsch, C., Dirk Lehmkuhl, Law and Legalization in Transnational Relations, Routledge Taylor \& Francis Group, 2007, p. 2, 9.

${ }^{9}$ http://www.iamsyria.org; http://www.bbc.com.

${ }^{10} \mathrm{http}: / / \mathrm{www} \cdot \mathrm{bbc} . \mathrm{com}$.

${ }^{11}$ You can see refugee population share among the neighbor states in the region: Syrian Regional Refugee Response (last updated 25 April 2015), The UN Refugee Agency; http://data.unhcr.org/syrianrefugees/regional.php. Date of Access: 2 May 2016.

DOI: $10.9790 / 0837-2109040112 \quad$ www.iosrjournals.org $\quad 2 \mid$ Page


population anywhere in the world probably. Migrant population becomes close to local population of some cities probably in Turkey. Turkish cities of Gaziantep, Hatay, Şanlıurfa and Kilis can be given as an example for this condition.

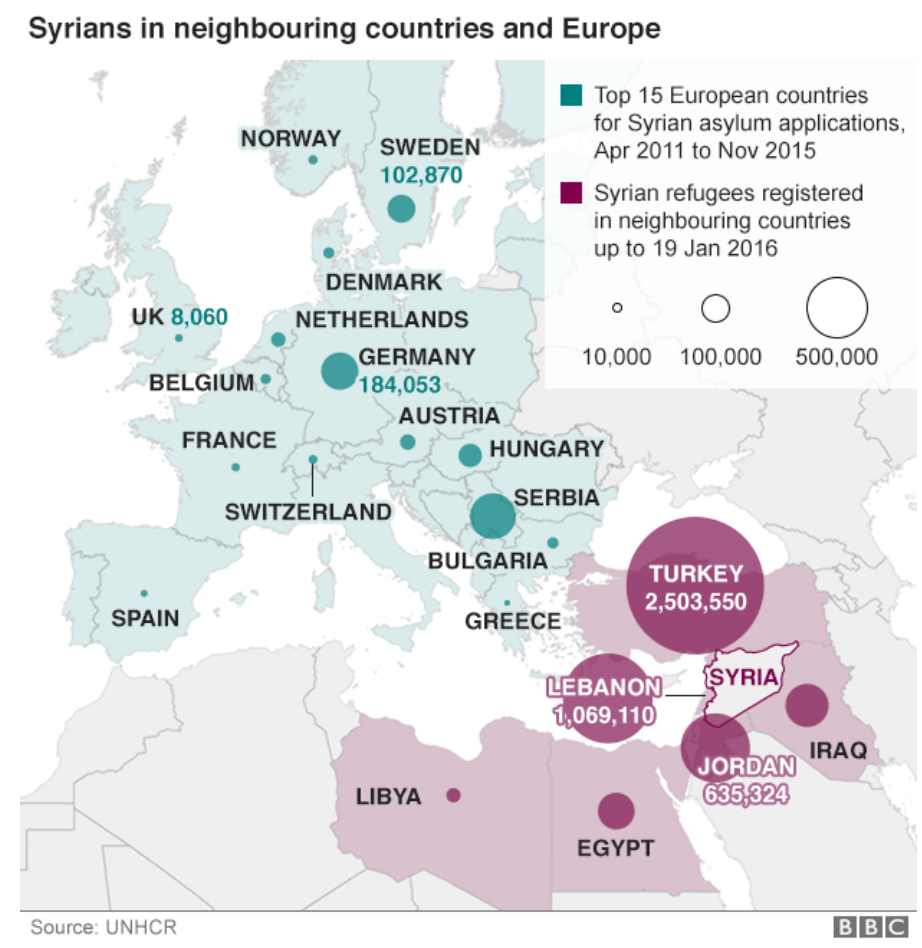

If we look in the Europe's states position for these migrants, we can see minor numbers relatively ${ }^{12}$. Now, their population closes to one million. Nevertheless, this number can be decreased likely because EU states apply different quotas ${ }^{13}$ for asylum. At this point EU tension increased because of different and heavier burden of Greece, Italy and Hungary than the other European states:"In September, EU ministers voted by a majority to relocate 160,000 refugees EU-wide, but for now the plan will only apply to those who are in Italy and Greece. Another 54,000 were to be moved from Hungary, but the Hungarian government rejected this plan and will instead receive more migrants from Italy and Greece as part of the relocation scheme" ${ }^{, 14}$.

UK statements are different than the other states. They prefer to use different frame for Syrian refugees. According to this; 1000 Syrian refugees were resettled under the Vulnerable Persons Relocation scheme in 2015. In addition, Prime Minister of UK said that UK would expand to accept up to 20,000 refugees from Syria over the next five years in Resettlement of Syrian Refugees Conference in Geneva, March $2016^{15}$.

\section{PROCESS OF THE EUROPEAN UNION - TURKEY DEAL AND AGREEMENT}

\section{A. Continuum of European Union - Turkey Refugee Deal}

EU - Turkey refugee agreement can be seemed new or sudden and urgent agreement. In fact, this was a period which has continued since 2013. In this period, EU member states and Turkey tendencies changed and differentiated. Meanwhile, Turkey and EU have negotiated approximately 10 years before the signing (28 November 2002). $5^{\text {th }}$ December 2013, European Commissioner for Enlargement Stefan Füle, European Commissioner for Home Affairs and Turkish Minister of Foreign Affairs (for this period) Ahmet Davutoğlu

\footnotetext{
${ }^{12}$ Europe's Syrian migrant population share can be seen: Syrian Regional Refugee Response (between April 2011 and February 2016), The UN Refugee Agency; http://data.unhcr.org/syrianrefugees/asylum.php. Date of Access: 3 May 2016.

${ }^{13}$ Migrant crisis: Migration to Europe explained in seven charts (4 March 2016) BBC New; http://www.bbc.com/news/world-europe-34131911. Date of Access: 2 May 2016.

${ }^{14} \mathrm{http} / / / \mathrm{www}$. bbc.com/news/world-europe-34131911.

${ }^{15}$ UK Statement on the Resettlement of Syrian Refugees Conference in Geneva (30 March 2016) GOV.UK; https://www.gov.uk/government/world-location-news/uk-statement-on-the-resettlement-of-syrian-refugeesconference-in-geneva. Date of Access: 3 May 2016.
} 
announced firstly in press conference. This was the first official announcement for the international public. Parties agreed and signed the agreement in 16 December 2013 and this agreement was named "the Agreement between the European Union and the Republic of Turkey on readmission of persons residing without authorization". We can say "Readmission Agreement" briefly.

In following period, 7 May 2014, with the publication of the Council decision on the conclusion of the EU-Turkey Readmission Agreement in its Official Journal, the EU has completed its ratification process and notified $^{16}$. Turkey also ratified and published official newspaper in 2 August 2014. It should be noted that, according to the Article 24/3; obligations of the Articles 4 and 6 shall only be applicable 3 years after (with referred 24/2). That is to say, during this period, they shall be only applicable stateless persons and nationals from third countries with which Turkey has concluded bilateral agreements or arrangements on readmission.

In the Agreement's Article 22/2, under the "Territorial Application" title, is specified that "this agreement shall not apply to the territory of the Denmark".In addition, this agreement shall not apply UK and Ireland territory, if they do not accept or "opt-in". This statement was put in the beginning of this agreement.

If we can look European Commission works for illegal migration, we can see many signed readmission agreements between EU and third parties ${ }^{17}$. Definition of readmission agreement:

"EU Readmission Agreements (EURAs) are based on reciprocal obligations and are concluded between the European Union and non-EU countries to facilitate the return of people residing irregularly in a country to their country of origin or to a country of transit. They operate alongside but take precedence over bilateral readmission agreements between individual EU Member States and non-EU countries. They are negotiated in a broader context where partner countries are usually granted visa facilitation and other incentives such as financial support for implementing the agreement or special trade conditions in exchange for readmitting people residing without authorization in the EU.",18

\section{B. Process of the European Union and Turkey and Its Outcome: Readmission Agreement or Not?}

If we can look from this direction and perspective, we can say that EU-Turkey readmission agreement could be an ordinary one but this agreement had different and vital importance for both sides in the time.

EU member states and Turkey's interest and also their domestic politics play important role to come this agreement but at the same time certain level of opposition can be seen in this process. Okay, but why is the "process" for the road of this agreement?

Process can be defined in international law area briefly: “...international law is a continuing process of authoritative decisions. This view rejects the notion of law merely as the impartial application of rules. International law is the entire decision-making process and not just reference to the trend past decisions which are termed rules. ${ }^{19,}$

If we use the definition which is the above, then, international law area should not be accumulation of rules. At the same time, this perspective requires to attention authoritative decision-making, domestic politics or political motivations/interests.

Parties' interests and tendencies can be seen easily on this agreement's articles. Thus, the agreement burdens some obligations for the readmission of third nationals (Section I/Article 4 for Turkey and Section II/Article 6 for the Union). In addition, agreement includes some financial resources are committed to making available to Turkey under the title of "Technical Assistance" (Article 23) by the Union. At this point, 3 billion euros financial assistance was released despite of Italy opposition. The reason of this, this financial assistance

\footnotetext{
${ }^{16}$ EU-Turkey Readmission Agreement is ratified by the European Union: a step towards visa liberalization, Delegation of the European Union to Turkey; http://avrupa.info.tr/resource-centre/news-archive/news-singleview/article/eu-turkey-readmission-agreement-is-ratified-by-the-european-union-a-step-towards-visaliberalisatio.html. Date of Access: 5 May 2016.

${ }^{17}$ We can see the list of Readmission Agreements between European Union and third party states, EUR-Lex (Access to European Union Law); http://eur-

lex.europa.eu/search.html?qid=1462827004288\&text=readmission\%20agreement\&scope=EURLEX\&type=quic k\&lang=en. Date of Access: 5 May 2016.

${ }^{18}$ EU Readmission Agreements: Facilitating the return of irregular migrants (24 April 2015), European Parliament Think Tank (EUROPARL); http://www.europarl.europa.eu/thinktank/en/document.html?reference=EPRS_BRI(2015)554212. Date of Access: 6 May 2016.

${ }^{19}$ Higgins, p. 2. 
was created 3 than 2 of national budgets of the member states. Nonetheless, at last, EU approves this financial assistance ${ }^{20}$.

Parties of this agreement gave some commitments and concessions to each other to achieve this agreement and also their expectations and interests:

The EU commitments:

- Turkey and EU "agreed that the accession process needs to be re-energized" after a decade of faltering negotiations.

- Three billion euros financial assistance to develop the situation.

- EU commits that the visas makes easier for Turks to obtain visas to European member states. It aims to lift visa requirements for Turkish citizens in Europe's borderless Schengen zone by October 2016 once Turkey meets EU requirements.

- 400.000 Syrian refugees shall be accepted officially and legal to EU zone. (Some numeral and procedural disagreements still are here- this condition had been reshaped and renewed "one-in, one-out"plan later ${ }^{21}$ ).

The EU demands from Turkey:

- Increased border security.

- Effective fight against human trafficking.

- Ratification of readmission agreement ${ }^{22}$.

Nevertheless, readmission agreement will come into force in June 2016. As far as we can understand parties expectations, their interests or politics (domestic/foreign) play an important role to shape this agreement and also its future. At this point, party states' governments are taking a position by their citizens' response. Both EU member states and Turkey have similar fractions.

In Turkey side, some part of the citizens oppose to readmission agreement because of their some economic problems and relatively low living and social standards and some of them also oppose this agreement by virtue of insufficient capacity for large numbers of refugees. Instead, they want to be distributed with equitable manner to all Turkey, Euro Region and neighbor countries of Middle East and North Africa. Some part of the society supports this agreement for its returns (Visa liberalization, entry to easier EU membership period...).

In EU member states side, some societies of the member states believe that the Turkish migration begins, if their states accept the Turkey to Schengen zone in return for accepting of Syrian refugees so they oppose their states commitments in this agreement. Other part of these societies defends readmission agreement because they want to decrease population of Syrian refugees in their lands. If we look these different domestic tendencies, we can see that their reflections (domestic policies and decision-making) shape positions of the agreement parties and their demands or commitments. For all these reasons, decision making and domestic policies processes lie behind this deal and agreement.

Romano Prodi said dramatically about this issue that "In recent months, the problem of refugees has led to an agreement that was supposed to reinvigorate the negotiations, taking into account the fact that, with nearly two million refugees who can push at any time to Europe, Turkey is in possession of a real atomic weapon" in his article which was published in Il Messaggero(The Messenger), 8 May $2016^{23}$.

20 Migrant crisis: EU approves 3 bn-euro fund for Turkey (3 February 2016) BBC News; http://www.bbc.com/news/world-europe-35486655. Date of Access: 6 May 2016.

21 Migrant crisis: EU and Turkey plan one-in, one-out deal (8 March 2016) BBC News; http://www.bbc.com/news/world-europe-35749837. Date of Access: 7 May 2016.

22 Terms of EU-Turkey migrant crisis deal (30 November 2015) EU Business; http://www.eubusiness.com/news-eu/europe-migrants.15d5. Date of Access: 7 May 2016.

${ }^{23}$ Prodi, R., "Se continua così, la Turchia rimarrà fuori dall'Europa fino alla fine dei tempi" [org. Italian text] (8 May 2016) romanoprodi.it; http://www.romanoprodi.it/articoli/se-continua-cosi-la-turchia-rimarra-fuoridalleuropa-fino-alla-fine-dei-tempi_12987.html. Date of Access: 11 May 2016: In addition, some kind evaluation of EU - Turkey readmission agreements and their commitments for: Yetkin, M., "The EU's point of no return with Turkey" (21 April 2016) Hürriyet Daily News; http://www.hurriyetdailynews.com/the-eus-pointof-no-return-with-turkey.aspx?PageID=238\&NID=98102\&NewsCatID=409. Date of Access: 12 May 2016.

DOI: $10.9790 / 0837-2109040112 \quad$ www.iosrjournals.org 5 |Page




\section{LEGALIZATION OF EU - TURKEY DEAL AND READMISSION AGREEMENT}

\section{What is the Legalization?}

"Legalization" is defined that "Legalization refers to a particular set of characteristics that institutions may (or may not) possess" 24 . Mainly, US based groups tend to make rationalist institutionalist research and also they explain the "legalization" term on the degrees of precision, obligation and delegation". In European view, it can be defined that; "...the shift from interest- and consensus-oriented bargaining to norm-oriented legal procedures that help structuring and resolving disputes about the interpretation and implementation of different elements of governance by with and without governments" ${ }^{26}$. According to other definitions; legalization can be may be combination of interests, regimes and governance mechanisms. Nonetheless, they criticize the tendency of concealment of the link between power and law ${ }^{27}$.

If we take US based groups definitions to measure legalization level of this process, then we need to define three elements of legalization: precision, obligation and delegation. At the same time, these are helpful elements to determine distinction between hard law and soft law (and also this agreements efficiency level) ${ }^{28}$. This distinction will be suitable to research the present and future of EU - Turkey readmission agreement. Who knows, maybe even a solution to the refugee crisis may help.

In first, we need to define these three elements which are the determinants of distinction between hard and soft law and also factors of ideal condition in international structure. According to this, obligation means that states or other (non-state actors possibly) actors are bound by set of rules or commitments (like EU -Turkey readmission agreement's rules and commitments). It should be noted that, these kind of bound purports legally means (general rules, domestic law procedures or regulatory works). Precision means that rules are defined detailed clearly to authorization or prohibition. Delegation means that third parties who are given representation authority to represent state or other actors personality on agreements, dispute resolutions ${ }^{29}$.

Abbott, Keohane, Moravcsik, Slaughter and Snidal work; "forms of international legalization" which is into the "Legalization and World Politics" book on page 22; it defines very well relationship between three elements, hard-soft law-anarchy structure and also their reflections to international agreements, procedures or

rules. According to this this scheme may be helpful to understand effects of these three elements on agreements and legalization level:

\footnotetext{
${ }^{24}$ Abbott, Kenneth W., Robert O. Keohane, Andrew Moravcsik, Anne-Marie Slaughter, and Duncan Snidal, The Concept of Legalization, Legalization and World Politics, The MIT Press, 2001,p. 17.

${ }^{25}$ Brütsch, p. 2;Abbott, p. 17.

${ }^{26}$ Brütsch, p. 2.

${ }^{27}$ Brütsch, p. 2.

${ }^{28}$ See distinction between Hard and Soft law: Abbott, Kenneth W., Duncan, Snidal, Hard and Soft Law in International Governance, International Organization, Vol. 54, 2000, p. 421, 422. Available at SSRN: http://ssrn.com/abstract=1402966.
}

29 Abbott, p. 17. 
The Syrian Refugees Crisis in Increasingly Fragmented

\begin{tabular}{|c|c|c|c|c|}
\hline Type & Obligation & Precision & Delegation & Examples \\
\hline $\begin{array}{l}\text { Ideal type: } \\
\text { Hard law } \\
\text { I }\end{array}$ & High & High & High & $\begin{array}{l}\text { EC; WTO- } \\
\text { TRIPs; } \\
\text { European } \\
\text { human } \\
\text { rights } \\
\text { convention; } \\
\text { International } \\
\text { Criminal Court }\end{array}$ \\
\hline II & High & Low & High & $\begin{array}{l}\text { EEC Antitrust, } \\
\text { Art. } \\
\text { WTO- } \\
\text { national } \\
\text { treatment }\end{array}$ \\
\hline III & High & High & Low & $\begin{array}{l}\text { U.S.-Soviet arms } \\
\text { control treaties; } \\
\text { Montreal } \\
\text { Protocol }\end{array}$ \\
\hline IV & Low & High & High (moderate) & $\begin{array}{l}\text { UN Committee } \\
\text { on Sustainable } \\
\text { Development } \\
\text { (Agenda 21) }\end{array}$ \\
\hline $\mathbf{V}$ & High & Low & Low & $\begin{array}{l}\text { Vienna Ozone } \\
\text { Convention; } \\
\text { European } \\
\text { Framework } \\
\text { Convention on } \\
\text { National } \\
\text { Minorities }\end{array}$ \\
\hline VI & Low & Low & High (moderate) & $\begin{array}{l}\text { UN specialized } \\
\text { agencies; World } \\
\text { Bank; OSCE } \\
\text { High } \\
\text { Commissioner } \\
\text { on National } \\
\text { Minorities }\end{array}$ \\
\hline VII & Low & High & Low & $\begin{array}{l}\text { Helsinki Final } \\
\text { Act; Nonbinding } \\
\text { Forest } \\
\text { Principles; } \\
\text { technical } \\
\text { standards }\end{array}$ \\
\hline
\end{tabular}




\begin{tabular}{|l|l|l|l|l|}
\hline VIII & Low & Low & Low & $\begin{array}{l}\text { Group of 7; } \\
\text { spheres of } \\
\text { influence; } \\
\text { balance of power }\end{array}$ \\
Ideal type: & & & & \\
\hline
\end{tabular}

\section{Evaluation of EU - Turkey Readmission Agreement by Means of Legalization Level}

If we adapt the "elements of legalization" the EU - Turkey deal process and also their readmission agreement, then we can find some data and signal to the future of this process. In addition, this may set light to evolve this agreement and its future efficiency.

Delegation of this deal process and agreement can be high relatively because on Turkey side, EU Affairs Minister and chief negotiators (from EgemenBağış to MevlütÇavuşoğlu) were the participants and Europe side, European commission Vice-President of the European Commission Frans Timmermans, Commissioner of Neighborhood and Enlargement Negotiations: Johannes Hahn, Migration and Home Affairs (Dimitris Avramopulos)attended in negotiations. In addition, we see that Chancellor of Germany: Angela Merkel and Turkey's Prime Minister: Ahmet Davutoğlu have active role in this process so this agreement's representation (delegation) power and capacity has high level sufficiently. Comparing to the others which are written in the scheme, delegation level can be high (moderate) segment possibly.

Joint readmission committee will be established and this committee shall be composed by representatives of Turkey and the Union (it shall be represented by the Commission) (see Article 19/1 and 19/3). That is to say, some kind of supervisory/monitory committee (regulatory (19/1(b)) and also advisory (19/1(d))) shall be established. This joint committee seems to be as monitory/regulatory organ in following period.

If we evaluate the precision level of this agreement, we can see that clear definitions and explanations which are about the terms (see Article 1). Nevertheless, this agreement does not include highly precise prohibitions or authorizations for the parties. Nonetheless, authorizations (implementing rules) of this agreement can be seen clear relatively (see Article 1/(k) and 20/1(a) "designation of competent local authorities"; border crossing points and exchange of contact points). Consequently, we can say that the agreement's rules are precise and clear with great majority (provisions may be much more detailed but details were reserved for the subsequent protocols (see Article 20/1)).

This agreement's obligations and distribution of these obligations are expressed with clear language to the contracting parties (see Turkey readmission obligations of third-country nationals and stateless persons Article 3 and the Union readmission obligation of third-country nationals and stateless persons Article 6). According to these provisions, if we look from Syrian refugee crisis, we can go to the Article 4/1(c): "...illegally and directly entered the territory of the Member States after having stayed on, or transited through, the territory of Turkey... all third-country nationals or stateless persons who do not, or who no longer, fulfil the conditions in force for entry to...". In addition, EU is committed to give financial resources in order to support for Turkey and also implementation of this agreement under the title of "Technical Assistance" in Article 23. These kinds of articles burden particular obligations on the contracting parties.

In my opinion, absence of enforcement rules or uncertainty situation in this agreement creates weakest point especially in case of violation of obligations (instead of binding decisions of the committee (Article 19/2) and precedence over any legally binding provisions of instruments between member states and Turkey in issues under the Article 20 (Article 21)). The proof is that; parties use non-legal arguments and political tools against each other (issues and conditions which are mentioned above) to fulfill their responsibilities. When the EU side uses the visa liberalization card to realize Turkey's readmission of Syrian refugees, Turkey side uses the card of releasing huge number of Syrian refugees (approximately 3 million) from own land to Eurozone. Unfortunately, these kind of mutual political maneuvers are too far from being effective legal-binding enforcement rule.Although this agreement includes clearly defined obligatory rules(by definition), these rules do not have highly binding feature.In addition, Article $24 / 5$ provides to be finished easily or in other words; it works like "escape clause" for the parties. According to the statement of the relevant article: "Each Contracting Party may denounce this Agreement by officially notifying the other Contracting Party. This Agreement shall cease to apply six months after the date of such notification".

Finally, if we evaluate the agreement's provisions and process and also put somewhere in the legalization scale, IV or VI categories seems appropriate and more suitable for the structural design of this agreement. In fact, obligatory rules were embedded into the agreement but they have whether binding character or not issue is 
problematic and they seem to be as weak from this perspective. This agreement character denotes "Soft Law" features because its legal arrangements are weakened with some of three elements; especially obligation (or lack of binding sanctions and their enforcement rules $)^{30}$. At this point, readmission agreement is much closer to soft law than the hard law. Return of this condition; this is creating more flexible areas for the parties but at the same time, lack of binding enforcement rule can be disadvantage for the agreement lifetime because this is becoming fragile and unstable to the process for the sides.

\section{EU - TURKEY READMISSION AGREEMENT IN FRAGMENTED INTERNATIONAL LAW}

Like many other special agreements which are depend to bound own their own "special regimes"31 or another namely; "self-contained" regimes, this readmission agreement creates own regime and also it includes set of special rules and principles as lex specialis ${ }^{32}$. It should be noted that readmission agreement is very beginning to implementation period so this will be tested over long period of time. Nevertheless, characterization of this agreement's rules display us that these rules contribute to increase fragmentation of international law.In general, some causes affect to fragmented nature of international law. These are; 1-Lack of centralized organs or institutions in international arena, 2-Increasing tendency of specialization in international law, 3-Different structured legal norms and characterized rules, 4-Paralelled and competitive regulations, 5Enlargement of the extent of international law, 6-Different regimes of secondary rules (regulatory, administrative rules $)^{33}$.

EU - Turkey readmission agreement provides an alternative way to general regime (UN and UN Charter) and at the same time it competes and conflicts other special regimes (Human Rights, Refugees, Humanitarian) such as; 1951 Convention Status of Refugees and its Protocol ${ }^{34}, 1950$ European Convention for the Protection of Human Rights and Fundamental Freedoms, 1984 Convention against Torture and other Cruel, Inhuman or Degrading Treatment or Punishment. In addition, 1963 dated Agreement for establishing Association between European Economic Community and Turkey (and also its protocols), European Council Decisions, case-law of the Court of Justice of the European Union and Directives of the Parliament and the Council ${ }^{35}$. In fact, Article 18 (Non-affection clause) provides provision that this agreement and its provisions shall not be prejudice to the rights, obligations and the responsibilities of the Union member states and Turkey where arising from international law and international agreements.

In following paragraphs of this article (1-3), it shall ensure that it shall not overlap and damage area of some international agreements, court decisions and directives which were mentioned above. At this point, however EU law allows the core principle of 1951 Geneva Refugee Convention and Protocol relating to the Status of Refugees; "non-refoulement rule", if we consider geographical exceptional clause of Turkey in 1967 protocol from its Article 1/B (1/2) (According to this, Turkey accepts migrants who come from Europe only under the definition of the Convention "refugee" title so migrants who are coming to Turkey, they utilize only "temporary protection" and they are classed "asylum seekers". That is to say; Syrian migrants are not refugees, they are "asylum seeker" and they are protected temporarily in the Turkey.), then this protection may be not legally-bound for the parties and also this situation can be legal gap. This condition may be not problematic to the Syrian refugees who are coming from the Europe to Turkey but at the same time important obstacle exists here to Syrian asylum seekers who want to go to the Union member states, using transit ways of Turkey. In addition, EU member states made some commitments to receive certain numbers of Syrian refugees from the

\footnotetext{
${ }^{30}$ Abbott (Hard and Soft Law in International Governance), p. 422.

${ }^{31}$ International Law Commission Report for United Nations General Assembly, Fifty-Eight Session, A/CN.4/L.702, 2006, p. 11.

${ }^{32}$ Report, p. 11; Shaw, Malcolm, N., International Law, Sixth Edition, Cambridge University Press, 2008, p. 66, 67.

${ }^{33}$ Hafner, G., Risk Ensuing From Fragmentation of International Law, International Law Commission Report for United Nations General Assembly, Fifty-Fifth Session, Supplement No. 10 (A/55/10), 2000, p. 326-331.

${ }^{34}$ For the full text of 1951 Convention relating to the Status of Refugees (1951 Geneva Convention), The UN Refugee Agency (UNHCR): http://www.unhcr.org/3b66c2aa10.html. Date of Access: 30 March 2016.

${ }^{35}$ For the full text of the readmission agreement; EUR-Lex (Access to European Union Law): http://eurlex.europa.eu/legal-content/EN/TXT/?uri=CELEX\%3A22014A0507(01). Date of Access: 29 March 2016.
} 
Turkey but again some member states are unwilling to receive Syrian refugee more and also numbers are not certain for now ${ }^{36}$.

Another problem is that Turkey is not seen "safe country" by the all member states but many member states ignore this reality to prevent and reduce migration of Syrian refugees. Some Syrian camps are very close to Turkey's South border line really and ISIS frequently strikes with rockets and mortars in recent times ${ }^{37}$. At this point, it is seen to be able to create de facto condition here instead of existed reality and stayed legal general principles and rules ${ }^{38}$.

Mentioned conditions-above show that some dangerous positions and legal loopholes may exist, if special regimes are established such as; EU - Turkey readmission agreement, virtually for the realization interests of contracting parties especially about "humanitarian" issues.

One hand, this agreement increases fragmentation in international law (It establishes much more special regime, when some special regimes already existed ${ }^{39}$ (Humanitarian regimes such as; 1951 Refugee Convention and EU Directives...). In addition, it challenges or provides alternative/escape way to general regimes (such as UN Charter and Universal Declaration of Human Rights Article 14)), its specialized regime ensures that parties engage in international law-making process and they tend to comply with this agreement's rules and regime ${ }^{40}$. Meanwhile, this kind of agreements causes to lose negatively reliability and credibility of international law in a certain time ${ }^{41}$.

\section{CONCLUSION}

If we look EU - Turkey readmission agreement, we can say that this agreement has high delegated-high (medium possible) precision-low obligation (low binding) character because contracting parties often use nonlegal tool (visa liberation and financial aid versus threat with releasing huge number Syrian refugees) in this process. Thus, this agreement is close to create soft law. Nonetheless, it can be flexible and more suitable for the interests of the parties but it may be weak and insufficient to fulfill humanitarian needs of the refugees.

One hand, this agreement increase the fragmentation of international law and also it contributes to lose credibility and reliability of international law, it ensure that EU member states and Turkey may engaged increasingly in international law-making processes and its special regime may be much more suitable for the parties' compliances on the other hand. Are general regimes or other special regimes really insufficient to apply for this refugee crisis? At the end, EU states and Turkey interests seem to play much more important role than Syrian refugees' humanitarian needs in this process. Nevertheless, certain number of reduction of the refugees, who immigrated to the Europe, has seen in recent times. In addition, Turkey started to distribute ID cards and registered to the Syrian refugees in own land. What about Turkey is really "safe country" for the refugees? If we take this question look in front, especially Turkey's Southern borders when ISIS threat has still existed. I think we need an honest approach here.

\footnotetext{
${ }^{36}$ Collett, E., "The Paradox of the EU-Turkey Refugee Deal" (March 2016), Migration Policy Institute (MPI); http://www.migrationpolicy.org/news/paradox-eu-turkey-refugee-deal. Date of Access: 10 May 2016. ${ }^{37}$ Jones, S., "Syrians Who Fled Terror Back Home Now Face ISIS Rockets in a Country the EU Deems 'Safe" (27 April 2016) The World Post; http://www.huffingtonpost.com/entry/kilis-turkey-syriansisis_us_5717980ee4b0018f9cbbc41b. Date of Access: 15 May 2016.

${ }^{38}$ Turkey 'illegally returning Syrian refugees' - Amnesty (1 April 2016), BBC

News;http://www.bbc.com/news/world-europe-35941947. Date of Access: 14 May 2016; Kaplan, M., "Syrian Refugees Forced Back To War Zone By Turkish Authorities As EU-Turkey Agreement Goes Into Effect" (4 April 2016), International Business Times; http://www.ibtimes.com/syrian-refugees-forced-back-war-zone-turkishauthorities-eu-turkey-agreement-goes-2348127. Date of Access: 15 May 2016; Frelick, B., "Is Turkey Safe for Refugees?" (22 March 2016), Human Rights Watch (HRW); https://www.hrw.org/news/2016/03/22/turkey-saferefugees. Date of Access: 16 May 2016; Kingsley, P., "Turkey is no 'safe haven' for refugees - it shoots them at the border" (1 April 2016), the guardian; http://www.theguardian.com/commentisfree/2016/apr/01/turkey-safehaven-refugees-shoots-border-illegal-deportations-syrians. Date of Access: 16 May 2016.

${ }^{39}$ Report, p. 11-12.

${ }^{40}$ Hafner, G., "Diversity or Cacophony?: New Sources of Norms in International Law Symposium: Article: Pros and Cons Ensuing from Fragmentation of International Law", Michigan Journal of International Law, Vol. 25, 2004, p. 859.

${ }^{41}$ Hafner (Pros and Cons), p. 856; Hafner (Commission Report), p. 331.
} 


\section{BIBLIOGRAPHY}

[1] 6 charts and a map that show where Europe's refugees are coming from - and the perilous journeys they are taking: Record numbers of people fleeing war, persecution and poverty are entering the EU" (2 September 2015); http://www.independent.co.uk/news/world/europe/refugee-crisis-six-charts-that-showwhere-refugees-are-coming-from-where-they-are-going-and-how-they-10482415.html. Date of Access: 2 April 2016.

[2] ABBOTT, Kenneth W., Duncan, SNIDAL, Hard and Soft Law in International Governance, International Organization, Vol. 54, 2000.

[3] ABBOTT, Kenneth W., Robert O. KEOHANE, Andrew MORAVCSIK, Anne-Marie SLAUGHTER, and Duncan SNIDAL, The Concept of Legalization, Legalization and World Politics, The MIT Press, 2001.

[4] “Başlangıcından Günümüze Suriye Krizi”; http://www.birgun.net/haber-detay/baslangicindan-gunumuzesuriye-krizi-104693.html. Date of Access: 2 April 2016.

[5] BRUTSCH, Christian, Dirk LEHMKUHL, Law and Legalization in Transnational Relations, Routledge Taylor \& Francis Group, 2007.

[6] COLLETT, Elizabeth, "The Paradox of the EU-Turkey Refugee Deal" (March 2016), Migration Policy Institute (MPI); http://www.migrationpolicy.org/news/paradox-eu-turkey-refugee-deal.Date of Access: 10 May 2016.

[7] Conflict Background, I am Syria; http://www.iamsyria.org/conflict-background.html. Date of Access: 3 April 2016.

[8] EU Readmission Agreements: Facilitating the return of irregular migrants (24 April 2015), European Parliament Think Tank (EUROPARL); http://www.europarl.europa.eu/thinktank/en/document.html?reference=EPRS_BRI(2015)554212. Date of Access: 6 May 2016.

[9] EU-Turkey Readmission Agreement is ratified by the European Union: a step towards visa liberalization, Delegation of the European Union to Turkey; http://avrupa.info.tr/resource-centre/news-archive/newssingle-view/article/eu-turkey-readmission-agreement-is-ratified-by-the-european-union-a-step-towardsvisa-liberalisatio.html. Date of Access: 5 May 2016.

[10] Europe's Refugee Crisis: An Agenda for Action (16 November 2015), Human Rights Watch; https://www.hrw.org/report/2015/11/16/europes-refugee-crisis/agenda-action. Date of Access: 11 April 2016.

[11] FRELICK, Bill, "Is Turkey Safe for Refugees?” (22 March 2016), Human Rights Watch (HRW); https://www.hrw.org/news/2016/03/22/turkey-safe-refugees.Date of Access: 16 May 2016.

[12] Full text of 1951Convention relating to the Status of Refugees (1951 Geneva Convention), The UN Refugee Agency (UNHCR): http://www.unhcr.org/3b66c2aa10.html. Date of Access: 30 March 2016.

[13] Full text of the readmission agreement; EUR-Lex (Access to European Union Law): http://eurlex.europa.eu/legal-content/EN/TXT/?uri=CELEX\%3A22014A0507(01). Date of Access: 29 March 2016.

[14] GOLDSTEIN, L. Judith, Miles KAHLER, Robert O. KEOHANE, Anne-Marie SLAUGHTER, Introduction: Legalization and World Politics, Legalization and World Politics, The MIT Press, 2001.

[15] HAFNER, Gerhard, "Diversity or Cacophony?: New Sources of Norms in International Law Symposium: Article: Pros and Cons Ensuing from Fragmentation of International Law”, Michigan Journal of International Law, Vol. 25, 2004.

[16] HAFNER, Gerhard, Risk Ensuing From Fragmentation of International Law, International Law Commission Report for United Nations General Assembly, Fifty-Fifth Session, Supplement No. 10 (A/55/10), 2000.

[17] HIGGINS, Rosalyn, Problems \& Process: International Law and How We Use It, Clarendon PressOxford, 1994.

[18] Historical process of Syrian Crisis; Syria: The Story of Conflict (11 March 2016), BBC News; http://www.bbc.com/news/world-middle-east-26116868. Date of Access: 2 April 2016.

[19] International Law Commission Report for United Nations General Assembly, Fifty-Eight Session, A/CN.4/L.702, 2006.

[20] JONES, Sophia, "Syrians Who Fled Terror Back Home Now Face ISIS Rockets in a Country the EU Deems 'Safe" (27 April 2016) The World Post; http://www.huffingtonpost.com/entry/kilis-turkeysyrians-isis_us_5717980ee4b0018f9cbbc41b. Date of Access: 15 May 2016.

[21] KAPLAN, Michael, "Syrian Refugees Forced Back To War Zone By Turkish Authorities As EU-Turkey Agreement Goes Into Effect" (4 April 2016), International Business Times; http://www.ibtimes.com/syrian-refugees-forced-back-war-zone-turkish-authorities-eu-turkey-agreementgoes-2348127. Date of Access: 15 May 2016. 
[22] KINGSLEY, Patrick, "Turkey is no 'safe haven' for refugees - it shoots them at the border" (1 April 2016), the guardian; http://www.theguardian.com/commentisfree/2016/apr/01/turkey-safe-havenrefugees-shoots-border-illegal-deportations-syrians.Date of Access: 16 May 2016.

[23] Migrant crisis: EU and Turkey plan one-in, one-out deal (8 March 2016) BBC News; http://www.bbc.com/news/world-europe-35749837. Date of Access: 7 May 2016.

[24] Migrant crisis: EU approves 3 bn-euro fund for Turkey (3 February 2016) BBC News; http://www.bbc.com/news/world-europe-35486655. Date of Access: 6 May 2016.

[25] Migrant crisis: Migration to Europe explained in seven charts (4 March 2016) BBC New; http://www.bbc.com/news/world-europe-34131911. Date of Access: 2 May 2016.

[26] PRODI, Romano, "Se continua così, la Turchia rimarrà fuori dall'Europa fino alla fine dei tempi" [org. Italian text] (8 May 2016) romanoprodi.it; http://www.romanoprodi.it/articoli/se-continua-cosi-la-turchiarimarra-fuori-dalleuropa-fino-alla-fine-dei-tempi_12987.html.Date of Access: 11 May 2016.

[27] SHAW, Malcolm, N., International Law, Sixth Edition, Cambridge University Press, 2008.

[28] "Suriye Krizi"; http://tr.sputniknews.com/trend/suriye_krizi/.Date of Access: 3 April 2016.

[29] Syria live map; http://syria.liveuamap.com/.9 April 2016.

[30] Syria's refugee crisis in numbers (3 February 2016), Amnesty International; https://www.amnesty.org/en/latest/news/2016/02/syrias-refugee-crisis-in-numbers/.Date of Access: 11 April 2016.

[31] Syrian Regional Refugee Response (last updated 25 April 2015), The UN Refugee Agency; http://data.unhcr.org/syrianrefugees/regional.php.Date of Access: 2 May 2016.

[32] Syrian Regional Refugee Response (between April 2011 and February 2016), The UN Refugee Agency; http://data.unhcr.org/syrianrefugees/asylum.php.Date of Access: 3 May 2016.

[33] Terms of EU-Turkey migrant crisis deal (30 November 2015) EU Business; http://www.eubusiness.com/news-eu/europe-migrants.15d5. Date of Access: 7 May 2016.

[34] The List of Readmission Agreements between European Union and third party states, EUR-Lex (Access to European Union Law); http://eurlex.europa.eu/search.html?qid=1462827004288\&text=readmission\%20agreement\&scope=EURLEX\&typ e=quick\&lang=en. Date of Access: 5 May 2016.

[35] The Sea Route to Europe: The Mediterranean passage in the age of refugees (1 July 2015), the UN Refugee Agency; http://www.unhcr.org/5592bd059.html. Date of Access: 10 April 2016.

[36] Turkey 'illegally returning Syrian refugees' - Amnesty (1 April 2016), BBC News; http://www.bbc.com/news/world-europe-35941947.Date of Access: 14 May 2016.

[37] UK Statement on the Resettlement of Syrian Refugees Conference in Geneva (30 March 2016) GOV.UK; https://www.gov.uk/government/world-location-news/uk-statement-on-the-resettlement-of-syrianrefugees-conference-in-geneva.Date of Access: 3 May 2016.

[38] YETKIN, Murat, "The EU's point of no return with Turkey" (21 April 2016) Hürriyet Daily News; http://www.hurriyetdailynews.com/the-eus-point-of-no-return-withturkey.aspx?PageID=238\&NID=98102\&NewsCatID=409.Date of Access: 12 May 2016. 